\title{
Book announcement
}

\section{GLOSSARIUM BIBLIOTHECARII MULTILINGUALE Dictionary of Book and Librarianship (German-English-Russian-Georgian), Compiled by Arne Ackermann, Tinatin Djachvadze, Davit Gagnidze, Iva Mindadze, Engelbert Plassmann and Claus Spies; Tinatin Djachvadze and Engelbert Plassmann, eds, Bad Honnef, Bock + Herchen, 2006}

International co-operation is a natural part of many aspects of the librarian's daily routine: international exchange of materials; acquisitions; international interlibrary loan; and professional communication via study tours, journal literature, and at conferences.

In this context, specialized encyclopaedias and dictionaries play an important role and serve important purposes. A German-Georgian initiative to publish a multilingual dictionary should, of course, also include English and Russian in addition to Georgian and German.

Criticism of any kind will be welcomed. If the work is well received and a second edition can be published, the suggestions of our users will be noted.

This Georgian-German co-operative project is part of the broader context of German-Georgian relations that have developed since Georgia regained its independence in 1991. This is occurring on a scale unimaginable a decade ago, and in a special way, only thanks to the generous and repeated return of books looted by the Soviet occupying forces to German libraries by the free Republic of Georgia since 1996.

We would like to extend our appreciation to a few colleagues who helped us in word and deed. In particular we would like to thank Dale Askey, Germanist and librarian at Yale University Library for the effort he took in correcting the English-German and German-English parts; he provided valuable advice and assisted the compilers in many other ways. Further, we would like to thank Guram Takniashvili of the National Library of the Georgian Parliament for his reading of the manuscript. We thank Tilman Lebert for his vital technical support.

We are especially grateful to Otar Karalashvili who took extended efforts in optimizing the dictionary in all its facets. Highly experienced in all four languages, he was able to eliminate inconsistencies and thus improve the quality of the work in many aspects. Furthermore, he originally designed the layout of the dictionary creating its user-friendly form.

"The new multilingual Dictionary of Book and Librarianship provides quick help to information specialists who focus on international communication with Eastern Europe. The dictionary combines an up to date vocabulary from the fields of computer technology and the new media with the well established terminology of librarianship and information science. It represents a reliable and easily accessible tool for professional communication with colleagues not only in Russia, Germany and Georgia. It also covers those Eastern European countries in which the languages of the dictionary are part of librarians' and information professionals' daily routine". 